\title{
Epistasis in intra- and inter-gene pool crosses of the common bean
}

\author{
J.C. Borel ${ }^{1}$, M.A.P. Ramalho² and A.F.B. Abreu ${ }^{3}$ \\ ${ }^{1}$ Colegiado de Engenharia Agronômica, Universidade Federal do Vale do São Francisco, \\ Petrolina, PE, Brasil \\ ${ }^{2}$ Departamento de Biologia, Universidade Federal de Lavras, Lavras, MG, Brasil \\ ${ }^{3}$ Embrapa Arroz e Feijão, Lavras, MG, Brasil \\ Corresponding author: J.C. Borel \\ E-mail: jeronimo.borel@univasf.edu.br \\ Genet. Mol. Res. 15 (1): gmr.15017573 \\ Received September 2, 2015 \\ Accepted November 26, 2015 \\ Published February 26, 2016 \\ DOI http://dx.doi.org/10.4238/gmr.15017573
}

ABSTRACT. Epistasis has been shown to have an important role in the genetic control of several quantitative traits in the common bean. This study aimed to investigate the occurrence of epistasis in intra- and inter-pool gene crosses of the common bean. Four elite lines adapted to Brazilian conditions were used as parents, two from the Andean gene pool (ESAL 686; BRS Radiante) and two from the Mesoamerican gene pool (BRSMG Majestoso; BRS Valente). Four $F_{2}$ populations were obtained: "A" (ESAL 686 x BRS Radiante), "B" (BRSMG Majestoso x BRS Valente), "C" (BRS Radiante x BRSMG Majestoso), and "D" (BRS Valente x ESAL 686). A random sample of $F_{2}$ plants from each population was backcrossed to parents and $F_{1}$ individuals, according to the triple test cross. Three types of progenies from each population were evaluated in contiguous trials. Seed yield and 100 -seed weight were evaluated. Dominance genetic variance was predominant in most cases. However, the estimates of genetic variance may be biased by the occurrence of linkage disequilibrium and epistasis. Epistasis was detected for both traits; however, the occurrence differed among the populations and between the two traits. The results of 
this study reinforce the hypothesis that epistasis is present in the genetic control of traits in the common bean and suggest that the phenomenon is more frequent in inter-gene pool crosses than in intra-gene pool crosses.

Key words: Phaseolus vulgaris L.; Triple test cross; Outbreeding depression

\section{INTRODUCTION}

The common bean (Phaseolus vulgaris L.) originated in the Americas and has been domesticated in at least two main regions, resulting in two major gene pools: Andean and Mesoamerican. Geographic isolation, combined with different soil, biotic and abiotic stresses associated with different climatic conditions, and human intervention have led to these two gene pools developing differences in various characteristics, such as growth form, phaseolin type, cycle duration, reaction to pathogens, and grain size (Gepts et al., 1986). Given the large diversity observed between Andean and Mesoamerican gene pools of $P$. vulgaris, several intergene pool crosses have been performed in recent decades, aiming to explore the diversity and broaden the genetic base of segregating populations (Beaver and Kelly, 1994; Johnson and Gepts, 1999; Singh, 2001; González et al., 2009). However, in some crosses of lines from these two gene pools, incompatibility reactions have been observed (Singh and Gutierrez, 1984; Gepts and Bliss, 1986). In several cases, even when the cross was viable, progeny was observed to have outbreeding depression for some quantitative traits, especially seed yield. A number of studies have reported the occurrence of epistasis as a probable explanation for the low performance of the segregant population (Singh and Urrea, 1995; Johnson and Gepts, 2002; Borel et al., 2013). However, few studies have been conducted to determine the occurrence of epistasis, or its importance, in the genetic control of traits in the common bean. In a recent study, Moreto et al. (2012) utilized the triple test cross analysis (TTC; Kearsey and Jinks, 1968) in an inter-gene pool cross, with the aim of studying the genetic control of some traits related to seed yield. Epistasis was observed to be significant for seed yield, number of seeds per plant, and number of pods per plant (Moreto et al., 2012). Johnson and Gepts (2002) also observed that epistasis played an important role in the genetic control of traits associated with yield in inter-gene pool crosses of the common bean. Both studies suggest that epistasis may be one of the causes of low performance of progenies from crosses between lines from different gene pools. However, most studies refer to inter-gene pools crosses, there is no information about the role of epistasis in intra-gene pool crosses. Understanding the role of epistasis in intra-gene pool crosses is important and can contribute to more efficient breeding strategies to increase seed yield. This study aimed to verify whether the occurrence of epistasis differs between intra- and inter-gene pool crosses of the common bean and evaluate its importance in the genetic control of traits associated with seed yield.

\section{MATERIAL AND METHODS}

Four elite lines of the common bean highly adapted to Brazilian crop conditions were used, two lines from the Andean gene pool: ESAL 686 and BRS Radiante, and two inbred lines from the Mesoamerican gene pool: BRS Valente and BRSMG Majestoso. All genotypes are cultivars recommended for the main crop regions of Brazil. The main characteristics of the inbred lines are described in Table 1. 
Table 1. Main characteristics of the inbred lines of the common bean used as parents in intra- and inter-gene pool crosses.

\begin{tabular}{|c|c|c|c|c|}
\hline Inbred line & Market class & 100 -seed weight $(\mathrm{g})$ & Mean cycle (days) & Growth form $^{c}$ \\
\hline ESAL $686^{a}$ & Jalo & 40 & 75 & $\mathrm{I}$ \\
\hline BRS Radiante $^{a}$ & Cranberry & 42 & 75 & 1 \\
\hline BRSMG Majestoso $^{b}$ & Carioca & 26 & 85 & III \\
\hline BRS Valente $^{\mathrm{b}}$ & Black & 22 & 90 & II \\
\hline
\end{tabular}

${ }^{\mathrm{a}}$ Andean gene pool; ${ }^{\mathrm{b}}$ Mesoamerican gene pool; ${ }^{\mathrm{C}}$ Growth form: I = determinate growth, upright plant type; II = indeterminate with short vines, upright plant type; III = indeterminate with long vines, semi-upright to prostrate plant type.

Four populations were obtained, two using parents from the same gene pool: "A" (ESAL 686 x BRS Radiante) and "B" (BRS Valente x BRSMG Majestoso), and two using parents from different gene pools: "C" (BRSMG Majestoso x BRS Radiante) and "D" (ESAL 686 x BRS Valente). The $F_{1}$ seeds were obtained in a greenhouse and they were later sown in a field to obtain the $F_{2}$ generation. A representative sample of plants from each of the four $F_{2}$ populations was grown in pots in a greenhouse and backcrossed to the respective parents $\left(P_{1}\right.$ and $\left.P_{2}\right)$ : "A" $\left(P_{1}-E S A L 686\right.$ and $\mathrm{P}_{2}$-BRS Radiante); "B" ( $\mathrm{P}_{1}$-BRSMG Majestoso and $\mathrm{P}_{2}$-BRS Valente); "C" ( $\mathrm{P}_{1}$-BRSMG Majestoso and $\mathrm{P}_{2}$-BRS Radiante); and "D" ( $\mathrm{P}_{1}$-BRS Valente and $\mathrm{P}_{2}$-ESAL 686), and to the $F_{1}$ of each cross, as recommended by the TTC analysis of Kearsey and Jinks (1968).

To facilitate identification of the crosses, female $F_{2}$ plants were used. The plants from the parents and from the $F_{1}$ generation were grown in beds near the greenhouse, from where flowers with pollen (male parents) were taken. Thus, for each $\mathrm{F}_{2}$ plant, backcrosses were obtained using the parents, $P_{1}\left(L_{1}\right)$ and $P_{2}\left(L_{2}\right)$ and using $F_{1}$ individuals $\left(L_{3}\right)$, generating " $3 n$ " progenies, where " $n$ " refers to the number of $F_{2}$ plants backcrossed with the testers (parents and $F_{1}$ ). This number was different for each population: "A", 33; "B", 28; "C", 23; and "D", 16.

As the number of seeds in the first generation of the backcrosses (TTC) was insufficient to proceed to field evaluation, the plants were selfed and the second generation of the backcrosses was obtained $\left(L_{1 \otimes}, L_{2 \otimes}, L_{3 \otimes}\right)$.

Field trials were carried out in the municipality of Lavras, south of Minas Gerais State, Brazil. The soil is classified as clay-loam oxisol, and the site is situated at $21^{\circ} 14^{\prime} \mathrm{S}$ and $45^{\circ} \mathrm{W}$; with an altitude of $910 \mathrm{~m}$. The climate is designated as tropical highland (Cwb) according to the climate classification of Köppen-Geiger.

Evaluation of the four populations was undertaken during the winter crop season in 2011. The "3n" progenies of each population ("A," 99; "B," 84; "C," 69; and "D," 48) were evaluated in experiments arranged in randomized blocks with three replicates. The four experiments were placed side by side in the field, and the experimental plots consisted of two rows $2 \mathrm{~m}$ in length, with 40 plants. Spacing between rows was $0.6 \mathrm{~m}$. At sowing, a $300-\mathrm{kg} / \mathrm{ha}$ dose of the formulated fertilizer 8:28:16 of $\mathrm{N}: \mathrm{P}_{2} \mathrm{O}_{5}: \mathrm{K}_{2} \mathrm{O}$ was applied, and in the first trifoliate leaf (V3) stage, $50 \mathrm{~kg} / \mathrm{ha}$ urea was applied. Sprinkler irrigation was used whenever necessary. Weed control was performed through application of herbicides registered for the crop, and fungicides and insecticides were not applied. The traits evaluated were: seed yield (SYD; g/plot) and 100-seed weight (100SW; g).

First, North Carolina Design III analysis was carried out for each trait, in each population, according to Jinks and Perkins (1970), considering the absence of epistasis. Selective accuracy was used to verify experimental precision, as described by Resende and Duarte (2007).

As the second generation of the backcrosses was used, the expected sum of variance $\left(\sigma_{\text {sum }}^{2}\right)$ remains equal to the original design, which is: 


$$
\sigma_{\text {sum }}^{2}=1 / 8 a^{2}\left(1 / 4 \sigma_{A}^{2}\right)
$$

In contrast, the difference in variance $\left(\sigma_{\text {dif }}^{2}\right)$ is based on Pooni et al. (1980) and Moreto et al. (2012):

$$
\sigma_{\text {dif }}^{2}=1 / 32 d^{2}\left(1 / 8 \sigma_{D}^{2}\right)
$$

The additive genetic variance $\left(\sigma_{A}^{2}\right)$, dominance genetic variance $\left(\sigma^{2}{ }_{D}\right)$, and the dominance ratio $(d / a)$ were estimated, respectively, using the following equations:

$$
\begin{gathered}
\sigma_{A}^{2}=4 \times \sigma_{\text {sum }}^{2} \\
\sigma_{D}^{2}=8 \times \sigma_{\text {dif }}^{2} \\
d / a=\sqrt{ }\left(2 \times \sigma^{2}\right) / \sigma_{A}^{2}
\end{gathered}
$$

The confidence intervals were also estimated for the variance components according to Steel et al. (1997). Subsequently, using the mean values from the North Carolina Design III analysis (attached), TTC analysis was carried out according to Jinks and Perkins (1970).

\section{RESULTS}

Results of the analysis of variance, according to North Carolina Design III analysis, for SYD and $100 S W$ in the four populations is presented in Table 2. Estimates of accuracy ranged from 83 to $94 \%$ for SYD and from 96 to $99 \%$ for 100 SW, showing good experimental precision. SYD varied among the populations (Table 2), with populations derived from intra-gene pool crosses ("A" and "B") showing a mean value greater than populations derived from inter-gene pool crosses. For $100 S W$, the population derived from parents of the Andean gene pool showed the greatest mean value $(38.81 \mathrm{~g})$, while the lowest mean was from the population of the Mesoamerican gene pool $(25.51 \mathrm{~g})$, as expected. The populations of inter-gene pool crosses showed intermediate values of $100 \mathrm{SW}$ compared to the values for populations of the intra-gene pool crosses.

The "tester" source of variation was significant in all populations for $100 \mathrm{SW}$; however, this was not the case for SYD in the populations derived from the crossing of parents from the same gene pool ("A" and "B"). $\sigma_{A}^{2}\left(L_{1 i \otimes}+L_{2 i \otimes}+L_{3 i \otimes}\right)$, which estimates the additive effect of genes, was significant $(P \leq 0.05)$ for both traits in all populations. $\sigma_{D}^{2}\left(L_{1 i \otimes}-L_{2 i \otimes}\right)$, which estimates the dominance effects of genes, was not significant in population "A" for either of the traits or in population "B" for SYD.

Most of the estimates of the variance components had positive lower limits for the confidence interval, indicating that there is $95 \%$ probability that the estimates are different to zero (Tables 3 and 4). The exception was the estimate of $\sigma^{2}{ }_{D}$ in population "A" for SYD, which was 
negative and may be interpreted as null. In general, the amplitude of the confidence intervals was greater for the estimates of $\sigma^{2}{ }_{D}$ than for all other components for the SYD trait. The large amplitude for the confidence intervals of the variance estimates reflects the low precision of some estimates, especially in the case of the estimate of $\sigma^{2}$ for SYD in population "B".

Table 2. Summary of North Carolina Design III analysis for seed yield (SYD) and 100-seed weight (100SW) in four common bean populations generated from intra $(A$ and $B)$ and inter-gene pool crosses $(C$ and $D)$.

\begin{tabular}{|c|c|c|c|c|c|}
\hline \multirow{2}{*}{\multicolumn{2}{|c|}{ Population }} & \multirow{3}{*}{\begin{tabular}{|l|} 
Source of variation \\
Testers \\
\end{tabular}} & \multirow{3}{*}{$\begin{array}{c}\begin{array}{c}\text { Degrees of } \\
\text { freedom }\end{array} \\
2 \\
\end{array}$} & \multicolumn{2}{|c|}{ Mean Squares } \\
\hline & & & & SYD & 100SW \\
\hline \multirow{6}{*}{$A$} & \multirow{6}{*}{$\begin{array}{l}\text { ESAL } 686 \\
\mathrm{x} \\
\text { BRS Radiante }\end{array}$} & & & $17,013.7^{\mathrm{NS}}$ & $33.63^{* *}$ \\
\hline & & $\operatorname{Sum}\left(L_{1 i \otimes}+L_{2 i \otimes}+L_{3 i \otimes}\right)$ & 32 & $18,096.4^{*}$ & $10.73^{* *}$ \\
\hline & & Difference $\left(L_{1 i \otimes}-L_{2 i \otimes}\right)$ & 32 & $7,191.9^{\mathrm{NS}}$ & $4.81^{\mathrm{NS}}$ \\
\hline & & Error & 196 & $10,582.67$ & 4.23 \\
\hline & & Accuracy $(\%)$ & & 87 & 96 \\
\hline & & Mean $(\mathrm{g})$ & & 568.02 & 38.81 \\
\hline \multirow{6}{*}{ B } & \multirow{6}{*}{$\begin{array}{l}\text { BRS Valente } \\
x \\
\text { BRSMG Majestoso }\end{array}$} & Testers & 2 & $4,926.23^{\mathrm{NS}}$ & $28.31^{\star *}$ \\
\hline & & $\operatorname{Sum}\left(L_{1 i \otimes}+L_{2 i \otimes}+L_{3 i \otimes}\right)$ & 27 & $30,235.43^{*}$ & $6.96^{\star \star}$ \\
\hline & & Difference $\left(L_{1 i \otimes}-L_{2 i \otimes}\right)$ & 27 & $21,629.93^{\mathrm{NS}}$ & $3.39^{\star *}$ \\
\hline & & Error & 166 & $17,662.33$ & 1.34 \\
\hline & & Accuracy $(\%)$ & & 83 & 98 \\
\hline & & Mean $(\mathrm{g})$ & & 537.01 & 25.51 \\
\hline \multirow{6}{*}{ C } & \multirow{6}{*}{$\begin{array}{l}\text { BRSMG Majestoso } \\
\text { X } \\
\text { BRS Radiante }\end{array}$} & Testers & 2 & $48,261.69^{* *}$ & $407.93^{\star *}$ \\
\hline & & $\operatorname{Sum}\left(L_{1 i \otimes}+L_{2 i \otimes}+L_{3 i \otimes}\right)$ & 22 & $15,856.55^{\star}$ & $45.55^{\star *}$ \\
\hline & & Difference $\left(L_{1 i \otimes}-L_{2 i \otimes}\right)$ & 22 & $15,484.66^{*}$ & $13.42^{* \star}$ \\
\hline & & Error & 136 & $9,254.43$ & 5.58 \\
\hline & & Accuracy (\%) & & 94 & 99 \\
\hline & & Mean $(\mathrm{g})$ & & 450.12 & 31.20 \\
\hline \multirow{6}{*}{$\mathrm{D}$} & \multirow{6}{*}{$\begin{array}{l}\text { ESAL } 686 \\
x \\
\text { BRS Valente }\end{array}$} & Testers & 2 & $40,863.59^{\star \star}$ & $486.33^{\star \star}$ \\
\hline & & $\operatorname{Sum}\left(L_{1 i \otimes}+L_{2 i \otimes}+L_{3 i \otimes}\right)$ & 15 & $17,182.93^{*}$ & $100.74^{\star \star}$ \\
\hline & & Difference $\left(L_{1 i \otimes}-L_{2 i \otimes}\right)$ & 15 & $22,302.52^{\star \star}$ & $18.04^{* *}$ \\
\hline & & Error & 94 & $9,328.56$ & 3.59 \\
\hline & & Accuracy (\%) & & 94 & 99 \\
\hline & & Mean (g) & & 395.28 & 29.56 \\
\hline
\end{tabular}

*,** Significant using the $F$-test at the $5 \%$ and $1 \%$ probability level, respectively; ${ }^{N S}$ not-significant.

Table 3. Estimates of variance components, additive $\left(\sigma_{A}^{2}\right)$, dominance $\left(\sigma^{2}\right)$, genetic $\left(\sigma_{G}^{2}\right)$, environmental $\left(\sigma^{2}\right)$, and dominance ratio $(d / a)$, for seed yield in four common bean populations generated from intra- $(A$ and $B)$ and inter-gene pool crosses (C and D).

\begin{tabular}{l|c|c|c|c}
\hline & Population A & Population B & Population C & Population D \\
\hline$\sigma^{2} A$ & $3,339.44$ & $5,588.04$ & $2,934.27$ & $3,490.83$ \\
\hline $\mathrm{LL}$ & $1,301.17$ & $2,177.30$ & $1,053.29$ & $1,120.25$ \\
\hline $\mathrm{UL}$ & $20,087.83$ & $33,614.31$ & $24,230.17$ & $48,528.73$ \\
\hline$\sigma^{2} D$ & $-4,521.03$ & $5,290.13$ & $8,306.97$ & $17,298.62$ \\
\hline $\mathrm{LL}$ & $-1,761.53$ & $1,052.99$ & $2,981.87$ & $6,740.16$ \\
\hline $\mathrm{UL}$ & $-27,195.03$ & $5,386,553.80$ & $68,595.97$ & $104,058.105$ \\
\hline$\sigma^{2} G$ & $3,339.44$ & $10,878.17$ & $11,241.24$ & $20,789.45$ \\
\hline$\sigma^{2} \theta$ & $10,582.7$ & $17,662.33$ & $9,254.44$ & $9,328.56$ \\
\hline$d / a$ & - & 1.37 & 2.38 & 3.15 \\
\hline
\end{tabular}

LL, lower and UL, upper limits of the $95 \%$ confidence interval.

For SYD, the estimates of $\sigma^{2}{ }_{A}$ were greater in populations "B" and "D". Nevertheless, there was no expressive difference among the populations. The confidence intervals overlap, indicating that the estimates do not differ among themselves. In contrast, the estimates of $\sigma_{D}^{2}$ showed more pronounced differences among the populations. The populations of inter-gene pool crosses ("C" and "D") showed estimates greater than those of populations "A" and "B" (Table 3). 
Table 4. Estimates of variance components, additive $\left(\sigma_{A}^{2}\right)$, dominance $\left(\sigma_{D}^{2}\right)$, genetic $\left(\sigma_{G}^{2}\right)$, environmental $\left(\sigma^{2}\right)$, and dominance ratio $(d / a)$, for 100 -seed weight in four common bean populations generated from intra- (A and $B$ ) and inter-gene pool crosses (C and D).

\begin{tabular}{l|c|c|c|c}
\hline & Population A & Population B & Population C & Population D \\
\hline$\sigma^{2} A$ & 2.89 & 2.50 & 17.76 & 43.17 \\
\hline $\mathrm{LL}$ & 1.45 & 1.43 & 9.95 & 23.14 \\
\hline $\mathrm{UL}$ & 8.35 & 5.47 & 39.95 & 107.37 \\
\hline$\sigma^{2} D$ & 0.77 & 2.73 & 10.45 & 19.27 \\
\hline $\mathrm{LL}$ & 0.15 & 1.34 & 4.57 & 6.76 \\
\hline $\mathrm{UL}$ & 770.70 & 8.43 & 43.32 & 59.29 \\
\hline$\sigma^{2} G$ & 3.66 & 5.23 & 28.21 & 62.44 \\
\hline$\sigma^{2} \theta$ & 4.23 & 1.34 & 5.57 & 3.59 \\
\hline$d / a$ & 0.73 & 1.48 & 1.08 & 0.94 \\
\hline
\end{tabular}

LL, lower and UL, upper limits of the $95 \%$ confidence interval.

For $100 \mathrm{SW}$, the difference among the populations based on estimates of the variance components was greater. Populations "C" and "D" showed greater estimates of $\sigma_{A}^{2}$ and $\sigma^{2}$ (Table 4). For SYD, the estimates of $\sigma_{D}^{2}$ were observed to be greater than the estimates of $\sigma_{A}^{2}$ in populations "C" and "D" (Table 3). For 100SW, this fact occurred only in population "B" (Table 4). The estimates of $d / a$ ranged from 0 (null) to 3.15 for SYD and from 0.73 to 1.48 for 100 SW.

The summary of the TTC analysis is presented in Table 5. For SYD, epistasis was detected in the populations from inter-gene pool crosses. In population " $\mathrm{C}$ ", only epistasis of the additive $\mathrm{x}$ additive [ $[$ ] type was significant, while in population " $D$ ", the additive $x$ additive [ $]$, the additive $x$ dominant, and the dominant $x$ dominant []$]+[/]$ epistasis were significant. For populations from intragene pool crosses ("A" and "B"), epistasis was not detected. For 100SW, epistasis was significant in populations "B", "C", and "D". The breakdown of epistasis showed that in population "B", both types were significant, while in populations " $C$ " and " $D$ ", only epistasis of the additive $x$ dominant and dominant $x$ dominant $[j]+[l]$ type were significant.

Table 5. Summary of the triple test cross analysis for seed yield (SYD) and 100-seed weight (100SW) in four common bean populations generated from intra- and inter-gene pool crosses.

\begin{tabular}{|c|c|c|c|c|c|}
\hline \multirow{2}{*}{\multicolumn{2}{|c|}{ Population }} & \multirow{3}{*}{$\begin{array}{l}\text { Source of variation } \\
\text { Epistasis }\end{array}$} & \multirow{3}{*}{$\begin{array}{c}\text { Degrees of freedom } \\
33 \\
\end{array}$} & \multicolumn{2}{|c|}{ Mean squares } \\
\hline & & & & SYD & $100 \mathrm{SW}$ \\
\hline \multirow{4}{*}{ A } & \multirow{4}{*}{$\begin{array}{l}\text { ESAL } 686 \\
\mathrm{x} \\
\text { BRS Radiante }\end{array}$} & & & $10,812.68^{\mathrm{NS}}$ & $4.87^{\mathrm{NS}}$ \\
\hline & & Epistasis [i] & 1 & $11,920.74^{\mathrm{NS}}$ & $0.37^{\mathrm{NS}}$ \\
\hline & & Epistasis []$+[]$ & 32 & $10,778.05^{\mathrm{NS}}$ & $5.01^{\mathrm{NS}}$ \\
\hline & & Error & 196 & $10,582.70$ & 4.23 \\
\hline \multirow{4}{*}{ B } & \multirow{4}{*}{$\begin{array}{l}\text { BRS Valente } \\
\mathrm{x} \\
\text { BRSMG Majestoso }\end{array}$} & Epistasis & 28 & $8,761.75^{\mathrm{NS}}$ & $5.34^{\star \star}$ \\
\hline & & Epistasis [i] & 1 & $4,626.45^{\mathrm{NS}}$ & $53.20^{\star \star}$ \\
\hline & & Epistasis []$+[]$ & 27 & $8,914.91^{\mathrm{NS}}$ & $3.57^{* \star}$ \\
\hline & & Error & 166 & $17,662.33$ & 1.34 \\
\hline \multirow{4}{*}{ C } & \multirow{4}{*}{$\begin{array}{l}\text { BRSMG Majestoso } \\
\mathrm{x} \\
\text { BRS Radiante }\end{array}$} & Epistasis & 23 & $15,836.94^{\star}$ & $15.40^{\star *}$ \\
\hline & & Epistasis [i] & 1 & $4,8847.85^{\star}$ & $16.18^{\mathrm{NS}}$ \\
\hline & & Epistasis []$+[]$ & 22 & $14,336.44^{\mathrm{NS}}$ & $15.37^{\star \star}$ \\
\hline & & Error & 136 & $9,254.435$ & 5.58 \\
\hline \multirow{4}{*}{ D } & \multirow{4}{*}{\begin{tabular}{|l} 
ESAL 686 \\
$x$ \\
BRS Valente
\end{tabular}} & Epistasis & 16 & $27,562.29^{\star \star}$ & $20.00^{\star *}$ \\
\hline & & Epistasis [i] & 1 & $58,539.01^{\text {** }}$ & $2.57^{\mathrm{NS}}$ \\
\hline & & Epistasis []$+[]$ & 15 & $25,497.18^{\star \star}$ & $21.16^{\star \star *}$ \\
\hline & & Error & 94 & $9,328.558$ & 3.59 \\
\hline
\end{tabular}

*,**Significant using the $F$-test at the $5 \%$ and $1 \%$ probability level, respectively; ${ }^{\mathrm{NS}}$ not-significant. 


\section{DISCUSSION}

Among the designs used in the study of genetic control of quantitative traits that allow detection of non-allelic interactions, the TTC proposed by Kearsey and Jinks (1968) stands out. This design is an extension of the North Carolina Design III (Comstock and Robinson, 1952). The TTC allows unambiguous detection of epistasis and in its absence estimates the components of genetic variance. This design has been employed in various species, such as maize (Khan and McNeilly, 2005), rice (Li et al., 2008), soybean (Barona et al., 2012), and the common bean (Moreto et al., 2012).

The common bean is a typical self-pollinated species that produces only a few seeds per pod. Thus, obtaining seeds from the $F_{1}$ generations of the three backcrosses in sufficient number to be able to evaluate the progenies in the field was a very difficult task. Therefore, selfed progenies of the backcrosses $\left(L_{1 \otimes}, L_{2 \otimes}, L_{3 \otimes}\right)$ were used. The use of selfed progenies in the TTC does not alter detection of epistasis or the estimation of additive variance; however, the coefficient that multiplies the dominance variance is $1 / 8$, whereas, when the $F_{1}$ of the TTC is evaluated it is $1 / 2$ (Pooni et al., 1980; Moreto et al., 2012). This fact contributes to the estimate of dominance variance being able to present a more accentuated bias. There are reports of the use of selfed progenies in the TTC by Kearsey and Jinks (1968), as well as its modifications, in Eragrostis tef (Tefera and Peat, 1997), in soybean (Barona et al., 2012), and in the common bean (Moreto et al., 2012).

Another important aspect is concerning the number of plants to be sampled in the $F_{2}$ generation. This number may vary from 20 to $40 \mathrm{~F}_{2}$ plants to obtain consistent estimates both of the additive effects and the dominance effects (Kearsey, 1980). In this study, the number of progenies of each backcross $\left(L_{1}, L_{2}\right.$, and $\left.L_{3}\right)$ was within the interval considered ideal in populations: "A" (33), "B" (28), and "C" (23). Only in population "D" was this number lower (16).

The evaluation of the progenies in only one environment can be questioned; however, it is worth emphasizing the difficulty in obtaining seeds for the three types of the TTC progenies beyond the experimental complexity required for this design. Most studies using the TTC refer to a single population. In this study, four populations were used, which were evaluated under the same conditions in replicated designs.

The estimates of genetic variance components were higher for populations " $C$ " and " $D$ ", which indicates that they have greater genetic divergence compared to populations " $A$ " and " $B$ " (Tables 3 and 4). The results agree with those obtained in a previous study made by Borel et al. (2013). The authors evaluated progenies derived from the same parents used in the current study and observed that inter-gene pool crosses showed higher estimates of genetic variance, heritability on a progeny mean basis, realized heritability, and expected gain with selection. However, the progenies from intra-gene pool crosses showed higher SYD and were equal to parents. In contrast, progenies from inter-gene pool crosses were inferior, indicating strong outbreeding depression (Borel et al., 2013). In the present study, mean SYD followed the same trend (Table 2).

The estimates of the variance components indicated the supremacy of the dominance effects in populations "C" and "D" for SYD, and in population "B" for 100SW (Tables 3 and 4). With the exception of population "A", some estimates of $d / a$ were greater than 1.0 , which in principle indicates the occurrence of over-dominance. Nevertheless, before making any inferences regarding the allelic interactions that may be present and in control of the traits using the estimates of the variance components, some comments are necessary. The first is that the estimates of $\sigma^{2}{ }_{D}$ are always associated with large confidence intervals, due to the larger error in calculating these estimates, as has already been discussed. Another important point is concerning the presence of linkage disequilibrium. Considering that the traits involved are controlled by various genes, it is 
expected that linkage occurs between them. Especially when linkage is in the repulsion phase, the dominance variance tends to be overestimated (Kearsey and Pooni, 1996). Moreover, this fact has already been proven by Gardner and Lonquist (1959) in maize. The authors obtained an estimate of 1.59 for $d / a$ for SYD in an $F_{2}$ generation of maize using North Carolina Design III analysis. Subsequently, they advanced the same population by six generations of random intercrossing $\left(F_{8}\right)$ to reach equilibrium and they obtained a new estimate of 0.93 . A final fact that may contribute to overestimating $\sigma_{D}^{2}$ is the presence of epistasis (Pooni et al., 1980). In this study, epistasis was detected in both traits, but its occurrence differed between the populations. Epistasis was more important in populations from inter-gene pools crosses ("C" and "D"). These populations showed greater estimates of $\sigma_{D}^{2}$. The predominance of dominance variance has already been observed in other situations in which the TTC was used. In Eragrostis tef Zucc. Trotter (t'ef), this occurred for SYD, biomass, harvest index, and days to maturity (Tefera and Peat, 1997). In the common bean, this fact was observed for yield and number of seeds per plant (Moreto et al., 2012).

Estimates of variance components for the common bean in the literature point to a predominance of additive effects. Ramalho et al. (2012) presents a compilation of estimates for the main quantitative traits of the common bean obtained using different methodologies. In all cases, predominance of additive variance was observed. According to Bernardo (2010), when the least squares method is used, predominance of additive variance is expected, unless there is epistasis, linkage, or over-dominance. Therefore, over-dominance is unlikely to occur in the genetic control of traits analyzed here. The presence of epistasis and possible linkage disequilibrium are likely to be the cause of "supremacy" of dominance variance in the current study.

For SYD, epistasis was not detected in the intra-gene pool crosses ("A" and "B"). Conversely, for the 100SW trait, epistasis was detected in populations " $B$ ", "C", and " $D$ ". The breakdown of epistasis showed that the additive $\mathrm{x}$ additive [i], additive $\mathrm{x}$ dominant, and dominant $x$ dominant []$+[/]$ types of epistasis were significant; however, there were differences between the traits and between the populations (Table 5). As described by Kearsey and Jinks (1968), the TTC is an efficient test for detection of non-allelic interactions for genes in which the parents differ. Following this logic, theoretically, the detection of non-allelic interactions in the inter-gene pool crosses is easier than in intra-gene pool crosses. Although there is genetic divergence between parents of the same gene pool, this divergence is lower than the divergence between lines of different gene pools. Wolf and Hallauer (1997) also comment that epistasis is more easily detected for less complex traits since they undergo less influence from the environment.

The occurrence of epistasis has great implications in plant breeding. In breeding programs of self-pollinating plants, such as the common bean, in principle, the most important type of epistasis is type [i] because the performance of inbred lines may depend on interactions of the additive $\mathrm{x}$ additive type. In addition, this type of epistasis may be capitalized by selection. The additive $\mathrm{x}$ dominant and dominant $\mathrm{x}$ dominant []$+[]$ types are only taken advantage of in species where hybrid production is exploited, since epistasis appears to be related to the occurrence of heterosis and inbreeding (Holland, 2001).

Another important implication is related to the efficiency of early selection. For characters in which epistasis plays an important role and linkage disequilibrium is present, early selection may be not effective (Yang, 2008). According to Bernardo (2010), the efficiency of early selection in a segregant population depends on the correlation between generations, so in the presence of non-allelic interactions this correlation is reduced, contributing to a low efficiency. This fact may explain why methods that delay selection of progenies using advanced endogamy, such as bulk and bulk within families, have been successful in selecting good lines in common bean programs (Ramalho et al., 2012). 
Although detection of epistasis using the TTC is often reported, mainly in self-pollinated plants (Holland, 2001), there are few reports in the common bean. One study was conducted by Moreto et al. (2012). The authors used the TTC of Kearsey and Jinks (1968) in a cross between the inbred lines Carioca MG (Mesoamerican gene pool) and BRS Radiante (Andean gene pool). Epistasis of the [] $+[/]$ type was observed to be present in the genetic control of the number of seeds per plant and in the number of pods per plant. For SYD per plant, all types of epistasis were significant. Another report on the detection of non-allelic interactions in the common bean was made by Johnson and Gepts (2002). Using the crossing of inbred lines from different gene pools, QTLs were mapped for several quantitative traits. Epistatic interactions among QTLs were found to explain a large part of the variation for traits, such as harvest index, days to maturity, and seed yield, indicating that epistasis performs an important role in genetic control of these traits.

In addition, other studies have raised the hypothesis that epistasis may be responsible for the low performance of segregating progenies from crosses between subgroups of the same species, as in the case of the Andean and Mesoamerican common beans (Singh and Urrea, 1995; Li et al., 1997; Johnson and Gepts, 1999). The hypothesis states that epistatic combinations present in each gene pool would be responsible for traits related to adaptation, and when these combinations are undone in the crosses, they contribute to the low performance of the progeny. The results of this study reinforce the hypothesis that epistasis is present in the genetic control of traits associated with SYD of the common bean and suggest that the phenomenon is more frequent in inter-gene pool crosses than in intra-gene pool crosses.

\section{Conflicts of interest}

The authors declare no conflict of interest.

\section{ACKNOWLEDGMENTS}

The authors thank Conselho Nacional de Desenvolvimento Científico e Tecnológico (CNPq) for financial assistance and scholarship support.

\section{REFERENCES}

Barona MAA, Colombari Filho JM, Santos VS and Geraldi IO (2012). Epistatic effects on grain yield of soybean. Crop Breed. Appl. Biotechnol. 12: 231-236. http://dx.doi.org/10.1590/S1984-70332012000400001

Beaver JS and Kelly JD (1994). Comparison of selection methods for dry bean populations derived from crosses between gene pools. Crop Sci. 34: 34-37. http://dx.doi.org/10.2135/cropsci1994.0011183X003400010005x

Bernardo R (2010). Breeding for quantitative traits in plants. 2nd edn. Stemma Press, Woodbury, Minnesota.

Borel JC, Ramalho MAP, de Carvalho VRF and Abreu ADFB (2013). Genetic and phenotypic parameters in common bean segregant populations from intra and inter-gene pool crosses of elite lines. Euphytica 193: 39-47. http://dx.doi. org/10.1007/s10681-013-0907-1

Comstock RE and Robinson HF (1952). Estimation of average dominance of genes. lowa State College Press, Ames, lowa.

Gardner CO and Lonquist JH (1959). Linkage and the degree of dominance of genes controlling quantitative characters in maize. Agron. J. 51: 524-528. http://dx.doi.org/10.2134/agronj1959.00021962005100090005x

Gepts P and Bliss FA (1986). Phaseolin variability among wild and cultivated common beans (Phaseolus vulgaris L.) from Colombia. Econ. Bot. 40: 469-478. http://dx.doi.org/10.1007/BF02859660

Gepts P, Osborn TC, Rashka K and Bliss FA (1986). Phaseolin-protein variability in wild forms of the common bean (Phaseolus vulgaris): evidence for multiple centers of domestication. Econ. Bot. 40: 451-468. http://dx.doi.org/10.1007/BF02859659

González AM, Rodiño AP, Santalla M and De Ron AM (2009). Genetics of intra-gene pool and inter-gene pool hybridization for seed traits in common bean (Phaseolus vulgaris L.) germplasm from Europe. Field Crops Res. 112: 66-76. http://dx.doi. org/10.1016/j.fcr.2009.02.003 
Holland JB (2001). Epistasis and plant breeding. In: Plant Breeding Reviews (Janick J, ed.). John Wiley \& Sons, Inc. New York, 27-112.

Jinks JL and Perkins JM (1970). A general method for the detection of additive, dominance and epistatic components of variation III: $F_{2}$ and backcross populations. Heredity 25: 419-429. http://dx.doi.org/10.1038/hdy.1970.42

Johnson WC and Gepts P (1999). Segregation for performance in recombinant inbred populations resulting from inter-gene pool crosses of common bean (Phaseolus vulgaris L.). Euphytica 106: 45-56. http://dx.doi.org/10.1023/A:1003541201923

Johnson WC and Gepts P (2002). The role of epistasis in controlling seed yield and other agronomic traits in an Andean x Mesoamerican cross of common bean (Phaseolus vulgaris L.). Euphytica 125: 69-79. http://dx.doi. org/10.1023/A:1015775822132

Kearsey MJ (1980). The efficiency of North Carolina Experiment III and the selfing, backcrossing series for estimating additive and dominance variation. Heredity 45: 73-82. http://dx.doi.org/10.1038/hdy.1980.51

Kearsey MJ and Jinks JL (1968). A general method of detecting additive, dominance and epistatic variation for metrical traits. Heredity (Edinb) 23: 403-409.http://dx.doi.org/10.1038/hdy.1968.52

Kearsey MJ and Pooni HS (1996). The genetical analysis of quantitative traits. Chapman \& Hall, London.

Khan AA and McNeilly T (2005). Triple test cross analysis for salinity tolerance based upon seedling root length in maize (Zea mays L.). Breed. Sci. 55: 321-325. http://dx.doi.org/10.1270/jsbbs.55.321

Li L, Lu K, Chen Z, Mu T, et al. (2008). Dominance, overdominance and epistasis condition the heterosis in two heterotic rice hybrids. Genetics 180: 1725-1742.http://dx.doi.org/10.1534/genetics.108.091942

Li Z, Pinson SRM, Park WD, Paterson AH, et al. (1997). Epistasis for three grain yield components in rice (Oryza sativa L.). Genetics 145: 453-465.

Moreto AL, Ramalho MAP and Bruzi AT (2012). Epistasis in an Andean x Mesoamerican cross of common bean. Euphytica 186: 755-760. http://dx.doi.org/10.1007/s10681-011-0578-8

Pooni HS, Jinks JL and Pooni GS (1980). A general method for the detection and estimation of additive, dominance and epistatic variation for metrical traits. IV Triple test cross analysis for normal families and their selfs. Heredity 44: 177-192. http://dx.doi.org/10.1038/hdy.1980.15

Ramalho MAP, Abreu AFB, Santos JB and Nunes JAR (2012). Aplicações da genética quantitativa no melhoramento de plantas autógamas. UFLA, Lavras.

Resende MDV and Duarte JB (2007). Precisão e controle de qualidade em experimentos de avaliação de cultivares. Pesq. Agropec. Trop 37: 182-194.

Singh SP (2001). Broadening the genetic base of common bean cultivars: a review. Crop Sci. 41: 1659-1675. http://dx.doi. org/10.2135/cropsci2001.1659

Singh SP and Gutierrez JA (1984). Geographical distribution of the DL1 and DL2 genes causing hybrid dwarfism in Phaseolus vulgaris L., their association with seed size, and their significance to breeding. Euphytica 33: 337-345. http://dx.doi. org/10.1007/BF00021130

Singh SP and Urrea CA (1995). Inter- and intra-racial hybridization and selection for seed yield in early generations of common bean, Phaseolus vulgaris L. Euphytica 81: 31-137. http://dx.doi.org/10.1007/BF00025424

Steel RGD, Torrie JH and Dickey DA (1997). Principle and procedures of statistics: a biometrical approach. McGraw-Hill Book Company, New York.

Tefera H and Peat WE (1997). Genetics of grain yield and other agronomic characters in t'ef (Eragrostis tef Zucc Trotter). II. The triple test cross. Euphytica 96: 193-202. http://dx.doi.org/10.1023/A:1002949028094

Wolf DP and Hallauer AR (1997). Triple test cross analysis to detect epistasis in maize. Crop Sci. 37: 763-770. http://dx.doi. org/10.2135/cropsci1997.0011183X003700030012x

Yang RC (2008). Effects of linkage and epistasis on intergeneration correlations in self-pollinated species. Crop Sci. 48: 20742078. http://dx.doi.org/10.2135/cropsci2008.02.0113 